\title{
Growth and physiological responses of maize inbreds and their related hybrids under sufficient and deficient soil nitrogen
}

\author{
Farag I. Ibraheem ${ }^{1,2}$, Eman M. El-Ghareeb ${ }^{1}$ \\ ${ }^{1}$ Botany Department, Faculty of Science, Mansoura University, Mansoura, Egypt, 35516 \\ ${ }^{2}$ Biology Department, AlQunfodah University College, Umm-Al Qura University, Saudi Arabia
}

\begin{abstract}
In this study, the effects of sufficient and deficient soil $\mathrm{N}$ on the growth and physiology performance of maize inbreds (B73, Mo17, Sids7 and Sids63) and hybrids $($ B $73 \times$ Mo17 and Sids $7 \times$ Sids63) were simultaneously monitored. This was done at rapid growth phase to have better understanding of the inbred/hybrid growth and physiological relationships. B73 and Sids7 maintained superior growth over Mo17 and Sids63. Their superiority was associated with larger leaf area, lower SLA, high levels of photosynthetic pigment, sucrose, ammonia-N, amino-N, total $\mathrm{N}$ and NUE under both $\mathrm{N}$ treatments. Hybrids surpassed their parental inbreds in growth and leaf features under the same $\mathrm{N}$ rates. Sids $7 \times$ Sid63 had higher biomass and faster growth rate than B73 $\times$ Mo17 and its superiority was associated with higher leaf area, smaller SLA and greater leaf N. N limitation reduced growth and physiological components in all genotypes, although at significantly different magnitudes. In contrast, limited $\mathrm{N}$ induced different levels of starch accumulation in all genotypes indicating variable degrees of disruption of source-sink relationships. The improved growth of B73, Sids7 and the hybrids under sufficient and limited $\mathrm{N}$ supply is shaped by a combination of larger leaf area, smaller SLA, higher leaf N, efficient resource utilization, and maintaining proper source-sink relations.

Keywords: maize, inbreds, hybrids, growth, physiology, nitrogen, carbohydrates.
\end{abstract}

\section{INTRODUCTION}

Nitrogen $(\mathrm{N})$ is a major limiting macro-nutrient for maize growth and productivity. The recent improvement in maize growth and productivity is associated with consumption of huge amounts of $\mathrm{N}$ fertilizers and genetic enhancement (Tollenaar and Lee, 2002; Han et al., 2015; Noor, 2017). The intensive use of $\mathrm{N}$ fertilizers for maize production is neither economic nor environmentally safe (Nazir et al., 2016). Therefore, searching for $\mathrm{N}$ efficient maize inbreds and hybrids that can maximize their growth and yield per available $\mathrm{N}$ units in soil is critical for continuous improvement of maize growth and productivity (Mastrodomenico et al., 2018; Das et al., 2019). Unfortunately, the physiological processes that shape high plant $\mathrm{N}$ utilization efficiency at different growth stages of many maize genotypes, particularly those of commercial significance, are not fully understood.

Rapid growth phase is a central stage in maize vegetative growth. During this stage, the fully expanded leaves and the green parts of the newly released leaves are photosynthetically active and represent source tissues for photoassimilates necessary for supporting the growth of sink tissues. The critical developmental events associated with maize rapid growth requires significant amount of $\mathrm{N}$ with more than $35 \%$ of total maize plant $\mathrm{N}$ is absorbed during this stage. The absorbed $\mathrm{N}$ is quickly metabolized into amino acids which are then used in synthesis of structural proteins, enzymes, nucleic acids, chlorophylls, and many other non-protein nitrogenous compounds necessary to drive the maize rapid growth (Masclaux-Daubresse et al., 2010). The complex chain of events in $\mathrm{N}$ metabolism is coordinated with photosynthetic carbon assimilation at both genetic and physiological levels to maintain a balance between vegetative growth and yield (Schlüter et al., 2012;
Jiang et al., 2018). Disruption of such balance can significantly alter maize growth, leaf features, physiology and productivity as reported in Illinois protein inbred lines that underwent long term selection for high and low grain proteins (Moose et al., 2004).

Maize inbreds and hybrids differ significantly in their $\mathrm{N}$ requirements as well as their efficiency in $\mathrm{N}$ absorption and utilization at different developmental stages (Chen et al., 2013; Xiang-ling et al., 2019). As a result, the term Nitrogen Use Efficiency (NUE) has been introduced to describe the translation of such genotypic differences in $\mathrm{N}$ metabolism and related processes into economic products such as biomass accumulation and/or grain yield per unit $\mathrm{N}$ supplied based on the growth stage under investigation (Worku et al., 2007, Noor, 2017). Significant genetic variability in NUE among maize inbreds and hybrids has been reported and such diversity along with the complexity of $\mathrm{N}$ metabolism have been major challenges of production of $\mathrm{N}$ efficient maize hybrids that efficiently absorb and utilize soil N (Hirel et al., 2007).

The genetic diversity in NUE among maize inbreds has been the driving force for efforts for production of $\mathrm{N}$ efficient maize hybrids. Recently, we have reported significant natural variation in growth and physiology among selected maize inbreds and hybrids without any supplemental $\mathrm{N}$ input during early vegetative growth (Ibraheem and El- Ghareeb, 2019). However, limited knowledge is available on the impact of such diversity on growth, physiology and their related traits during rapid growth phase. Therefore, the objectives of the current study were to (1) assess the general and/or genotype-specific growth and physiological responses to sufficient and deficient $\mathrm{N}$ inputs in a set of important parental inbred lines (B73, Mo17, Sids7 and Sids63) and hybrids $($ B73 $\times$ Mo17 and Sids7 $\times$ Sids63), (2) have a better understanding of how possible genotypic 
growth and physiological differences in inbreds would be inherited into their single cross hybrids under different $\mathrm{N}$ availability and (3) how such differences among inbreds and hybrids relate to their NUE.

\section{MATERIALS AND METHODS}

\section{Genetic stocks}

Four maize inbreds of different origins (US lines; B73 and Mo17 and Egyptian lines; Sids7 and Sids63) and their hybrids $($ B73 $\times$ Mo17 and Sids7 $\times$ Sids63) were used in this study. These genotypes were selected because of their economic and scientific values in both US and Egypt (Sharopova et al., 2002; Mousa et al., 2017). The original B73 and Mo17 seeds were obtained from Dr. Stephen Moose at the University of Illinois, USA. Enough inbred and hybrid seeds were produced by the authors via selfing and crossing the selected inbreds, respectively.

\section{Field site and experimental design}

The experimental field was divided into four main plots: two for inbreds and two for hybrids. Plots used had $3 \mathrm{~m}$ long rows that were $50 \mathrm{~cm}$ apart. Each plot was sectioned into subplots of four rows for each inbred and eight rows for each hybrid. Seeds were sown with a $25 \mathrm{~cm}$ between hills. At V2 stage, plants were thinned to one plant per hill and irrigation was applied once a week. Each genotype received two rates of $\mathrm{N}$ fertilizers: high $\mathrm{N}(120 \mathrm{~kg} \mathrm{~N} /$ faddan, equivalent to $285.7 \mathrm{~kg} \mathrm{~N} \mathrm{ha}^{-1}$ ) and low $\mathrm{N}$ (30 kg $\mathrm{N} /$ faddan equivalent to $71.4 \mathrm{~kg} \mathrm{~N} \mathrm{ha}^{-1}$ ). The fertilizer was applied down the center of the row as ammonium nitrate at 25 days after sowing (DAS). Plant samples were harvested at 45 days and processed for downstream analyses.

\section{Growth analysis}

Measurements of growth parameters were carried out using ten randomly selected plants per maize genotype. Plant heights were measured from soil surface to the tip of the most recent extending leaf from the whorl using a measuring tape. Numbers of leaves with visible collars on each plant were recorded. Leaf features were monitored on the uppermost fully expanded leaf with a visible collar. Leaf length and breadth were determined using a measuring tape and the leaf area was determined according to Hunt et al., (1978). Specific leaf area (SLA, $\mathrm{cm}^{2} \mathrm{~g}^{-1}$ leaf weight) for each plant was calculated as described by Zhang et al., (2015).

Biomass accumulation in leaves and aboveground plant parts and crop growth rate (CGR) were measured using six representative plants. The laminas of all leaves from each plant were separated and that of the uppermost fully extended leaf from each plant was labeled. The plant materials were then dried in an electric oven at $80{ }^{\circ} \mathrm{C}$ for 72 hours and the dry weights were determined using a sensitive digital balance. CGR (g/day) was measured over a 20-day long period (25 DAS-45DAS) using biomass accumulation data at both time points according to Beadle (1987).

\section{Physiological analysis}

Physiological analyses were carried on the same set of plants that were used in monitoring biomass accumulation to correlate the obtained biomass data with the physiological status of the leaf.

Extraction and estimation of photosynthetic pigment

Known weights from comparable locations on both sides of the midrib of the middle part of the uppermost fully expanded leaf were extracted in $80 \%$ acetone. The levels of chlorophyll a (Chl a), chlorophyll b ( Chl b) and carotenoids (Cars) were determined spectrophotometrically and expressed as $\mathrm{mg} / \mathrm{g}$ fresh weight (Metzner et al., 1965).

\section{Extraction and estimation of carbohydrates}

Known weights of dry leaf tissues were extracted in $80 \%$ ethyl alcohol and the alcoholic extracts were used for analysis of sucrose using anthrone reagent (Handel, 1968). Sugar-free residues were dried and used for determination of starch content according to Thayennanavan and Sadasivam (1984).

Extraction and estimation of nitrogenous constituents

Known weights of dry leaf tissues were ground in distilled water according to Yemm and Willis (1956). The levels of ammonia-N and amino-N were determined spectrophotometrically by Nessler's reagent and ninhydrin as described by Naguib (1964) and Muting and Kaiser, (1963); respectively. Total nitrogen was determined directly in the powdered tissues by Kjeldahl method (Chinbal et al., 1943).

\section{Statistical analysis}

Data were statistically analyzed using COHORT/ COSTAT program (798 Lighthouse Ave. PMB 329, Monterey, CA, 93940, USA). The least significant difference (LSD) test was used to compare means with significance level at $\mathrm{P} \leq 0.05$.

\section{RESULTS}

\section{Effect of sufficient and deficient $\mathrm{N}$ application on growth of inbreds and hybrids}

\section{Plant height}

Both inbreds and hybrids differed significantly in their plant heights under sufficient and limited $\mathrm{N}$ supply (figure. 1A). Under both $\mathrm{N}$ rates, B73 plants were the tallest whereas Sids63 were the shortest among inbreds. Sids7 and Mo17 showed intermediate plant heights with Sids7 being significantly taller than Mo17. In hybrids, B73 × Mo17 exhibited significantly taller plants than Sids $7 \times$ Sids63 under both $\mathrm{N}$ rates. Compared to inbreds, B73 $\times$ Mo17 had taller plants than its better parent (B73) under high $\mathrm{N}$ supply, however its height was within the range of its parents under low N. Sids $7 \times$ Sids63 plants had intermediate values to those of its parental inbreds under both $\mathrm{N}$ rates. Compared to high $\mathrm{N}$ input, $\mathrm{N}$ deprivation significantly reduced plant heights in inbreds and hybrids. In inbreds, low $\mathrm{N}$ - induced height reduction of $-10 \%,-17 \%,-13 \%$ and $-19.48 \%$ were obtained in B73, 
Mo17, Sids7, and Sids63, respectively. In hybrids, the limited $\mathrm{N}$-induced reduction in plant heights was $29.38 \%$ in B73 $\times$ Mo17 and $-15.10 \%$ in Sids $7 \times$ Sids63.

\section{Leaves number per plant}

Figure 1B shows the effects of both genotypic and soil $\mathrm{N}$ availability on the number of leaves per plant in the tested genotypes under sufficient and deficient soil $\mathrm{N}$ at the rapid growth phase. Our data revealed neither genotypic difference nor $\mathrm{N}$ supply influence on the number of leaves per plant in the tested inbreds and hybrids.

\section{Leaf area}

Figure $1 \mathrm{C}$ reveals significant differences $(p \leq 0.05)$ in leaf area among most of the tested inbreds under both $\mathrm{N}$ rates. Under high $\mathrm{N}$, Sids7 had the largest leaf area whereas Mo17 maintained the smallest among inbreds. Sids63 and B73 had relatively similar intermediate leaf area. Under N-deficient, Sids63, Sids7, and B73 tended to have relatively similar leaf area that was significantly higher than that of Mo17. Compared to inbreds, both hybrids had significantly larger leaf area under adequate and limited-N inputs.
Sids7 $\times$ Sids63 had significantly larger leaf area than those of B73 $\times$ Mo17 under adequate and limited-N treatments. Limited-N significantly reduced leaf area in all inbreds and hybrids; however, the magnitude of such low $\mathrm{N}$-induced reduction varied significantly among genotypes.

In inbreds, the percentages of reductions in the leaf area were $-17.99 \%,-18.97 \%,-40.98 \%$ and $-14.06 \%$ in B73, Mo17, Sids7, and Sids6, respectively. In hybrids, the limited-N induced reductions were $-24.18 \%$ and $26.65 \%$ in $\mathrm{B} 73 \times \mathrm{Mo} 17$ and Sids7 $\times$ Sids63, respectively.

\section{Biomass accumulation in leaves and aboveground parts}

Our results revealed significant differences in leaves biomass among most of the tested inbreds and hybrids (figure 2a). Under high N, B73 and Sids7 accumulated the highest leaves biomass without significant difference between the two inbreds. Sids63 has significantly higher leaves biomass than Mo17. Under low N, B73 and Mo17 attained the highest and the lowest leaves biomass among inbreds, respectively.
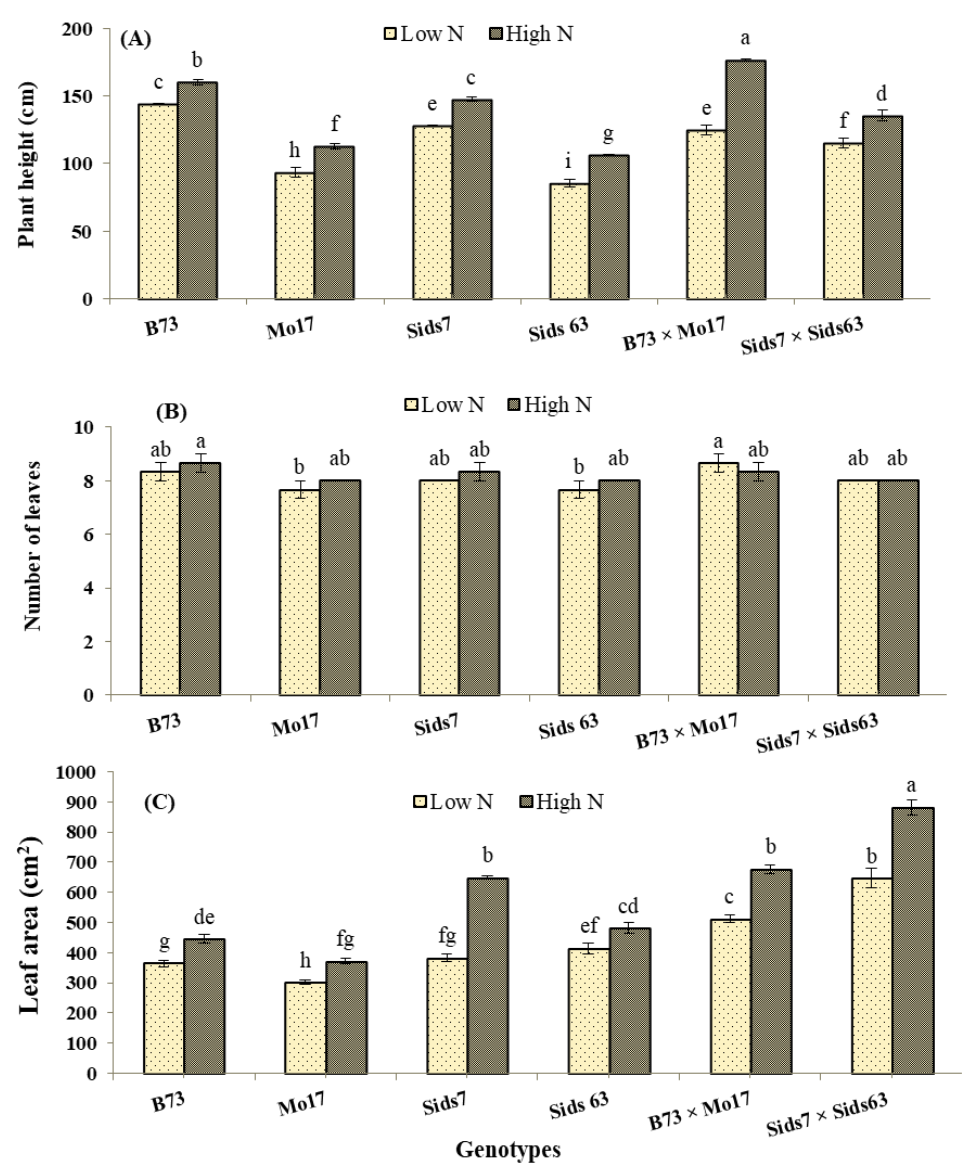

Figure (1): Plant morphological traits of maize inbreds and hybrids at 45 days grown under low and high $\mathrm{N}$ input levels, (A) Plant height; (B) Numbers of leaves; (C) Leaf area. Bars with different letters are significantly different $(p \leq 0.05)$. Standard errors are not shown when they are small than the bar line. Values are means \pm standard error. 
Sids7 and Sids63 showed intermediate levels of leaves biomass without significant difference in-between. Compared to inbred, Sids7 $\times$ Sids63 accumulated 2.1 and 2.8 fold higher biomass in its leaves than its better parent (Sids7) under high and low $\mathrm{N}$ rates, respectively. On the other hand, B73 $\times$ Mo17 had relatively similar leaf biomass compared to its better parent (B73) grown under both $\mathrm{N}$ rates. Meanwhile, inbred Sids7 $\times$ Sids63 recorded approximately two folds higher biomass accumulation, in its leaves, than genotype B73 $\times$ Mo17. Decreasing N input signifycantly reduced leaves biomass in all genotypes. Such low N-elicited reduction, in accumulative leaf biomass, reported $-20.59 \%,-10.28 \%,-45.14 \%,-16.47 \%$ for B73, Mo17, Sids7, and Sids63, respectively. In hybrids, the percentages of reductions in both genotypes, B73 $\times$ Mo17 and Sids $7 \times$ Sids63, were $-19.77 \%$ and $-26.0 \%$, respectively.

Figure $2 b$ showed that the four inbred lines maintained the same statistics relations (B73>Sids7 $>$ Mo17>Sids63) under both $\mathrm{N}$ rates. In hybrids, B73 $\times$ Mo17 plants tended to have aboveground biomass similar to its better parent (B73) under high $\mathrm{N}$ and to its mid-parent under low N. Sids7 $\times$ Sids63 plants accumulated 2.3 and 2 folds higher aboveground biomass than its better parent (Sids7) under deficient and sufficient $\mathrm{N}$ fertilization rates, respectively. Also, Sids7 $\times$ Sids63 accumulated two folds higher aboveground biomass than B73 $\times$ Mo17 under both $\mathrm{N}$ rates.
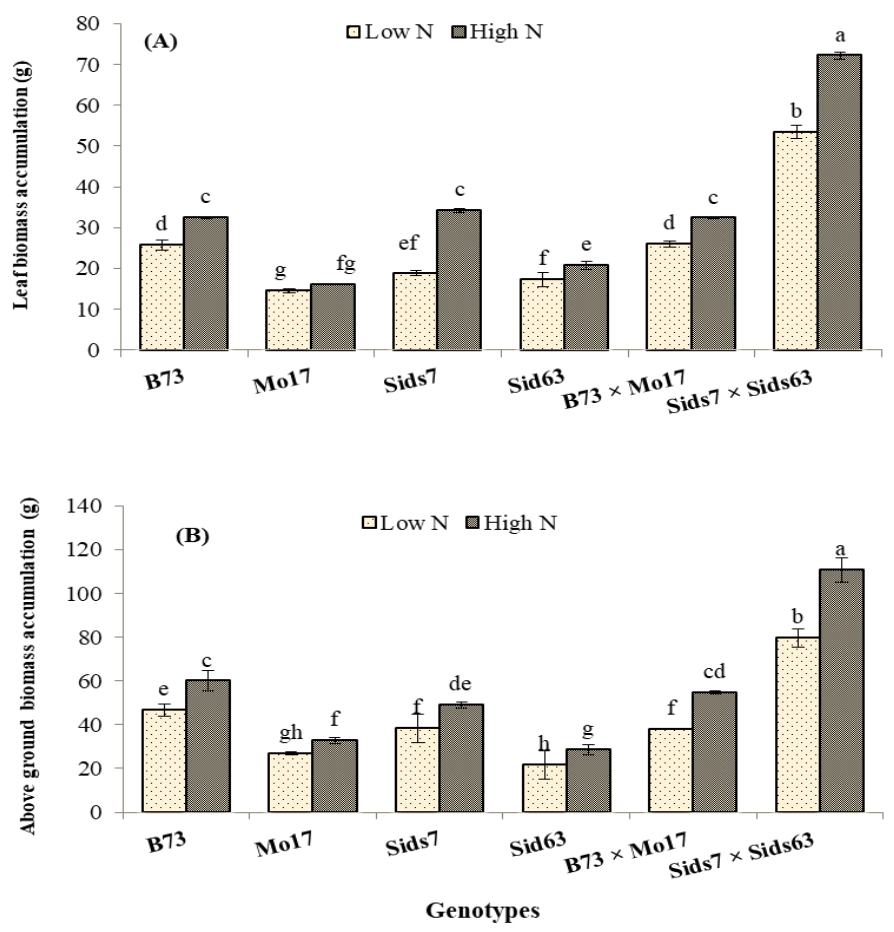

Figure (2): Biomass accumulation in leaves and aboveground parts of maize, inbreds and hybrids, harvested at 45 days of planting and grown under low and high $\mathrm{N}$ input levels. (A) Leaves biomass accumulation; (B), Above ground biomass accumulation. Bars with different letters are significantly different $(p \leq 0.05)$. Values are means \pm standard error.

\section{Specific leaf area (SLA)}

SLA significantly changed among most of the tested inbreds under both $\mathrm{N}$ rates (figure $3 \mathrm{~A}$ ). Under high $\mathrm{N}$, Sids63 and Mo17 had the highest SLA without significant differences in-between. Sids7 exhibited significantly higher SLA than B73. Under low N, Sids63 and B73 had the highest and lowest SLA among inbreds, respectively. Sids7 and Mo17 had intermediate SLA without significant difference between both inbreds. Compared to their parents, B73 $\times$ Mo17 had SLA similar to its higher parent (Mo17) under sufficient and deficient $\mathrm{N}$ conditions whereas $\operatorname{Sids} 7 \times$ Sids63 had significantly lower SLA than its lower parent (Sids7). Also, B73 $\times$ Mo17 had about two folds higher SLA than Sids7 $\times$ Sids63. Compared to high N trial, low $\mathrm{N}$ induced either insignificant change (B73, Sids63, and Sids7) or significant decrease (Mo17) in SLA. However, in hybrids, decreasing $\mathrm{N}$ application did not influence SLA.

\section{Crop growth rate (CGR)}

Significant genotypic differences in CGR were observed under adequate and limited $\mathrm{N}$ fertilization (figure 3B). Under adequate N, B73 followed by Sids7 showed significantly higher CGR than the other two inbreds. Mo17 exhibited significantly higher CGR than Sids63. Under limited N, B73, Sids7, and Mo17 had relatively similar CGR records whereas sids63 maintained the lowest CGR among inbreds. Compared to inbreds, B73 $\times$ Mo17 had similar CGR to its lower parent (Mo17) under both $\mathrm{N}$ rates whereas Sids7 $\times$ 
Sids63 had significantly higher CGR than its better parent $($ Sids7). Sids7 $\times$ Sids63 had more than two folds higher CGR than B73 $\times$ Mo17 under both N rates. Ndeprivation resulted in $-30 \%,-20.6 \%,-29 \%$, and $-37 \%$ decrease in CGR in B73, Mo17, Sids7, and Sids63, respectively. In hybrids, N-limitation caused $-33.42 \%$ reduction in Sids7 $\times$ Sids63 compared to $-50.23 \%$ in B73 × Mo17.
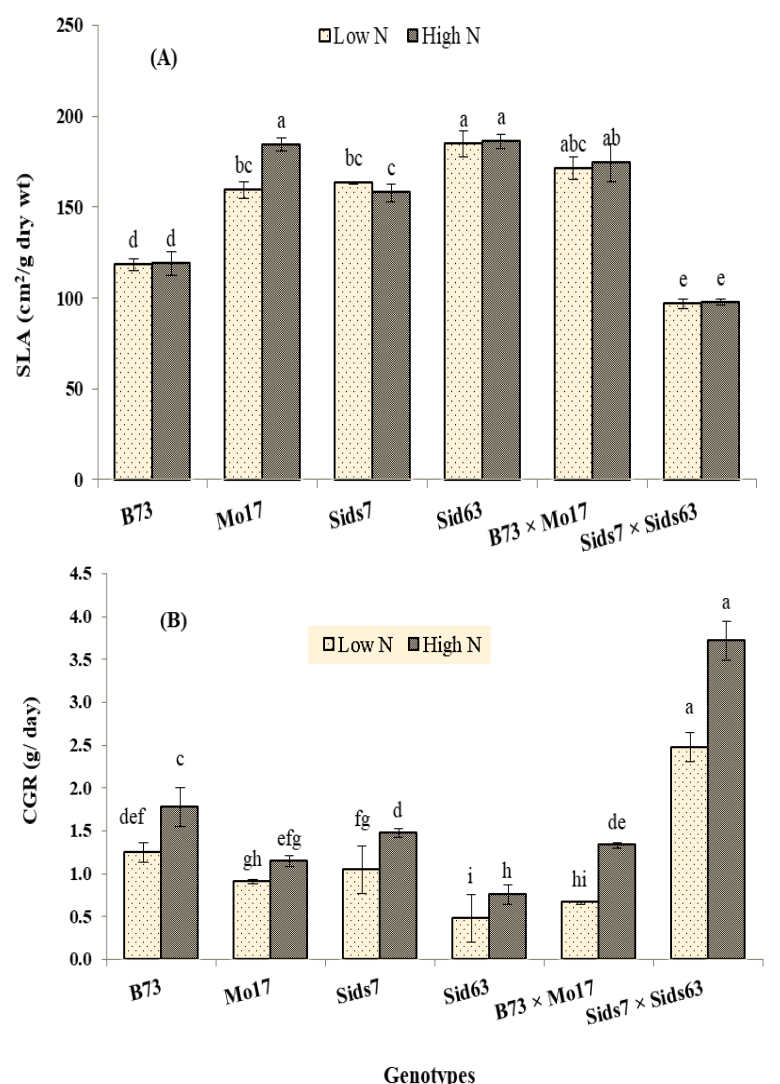

Figure (3): Specific leaf area and growth rate of maize, inbreds and hybrids, harvested at 45 days of planting and grown under low and high N inputs. (A), Specific leaf area, SLA; (B), Crop growth rate, CGR. Bars with different letters are significantly different $(p \leq$ $0.05)$. Values are means \pm standard error.

\section{Physiological responses}

\section{Photosynthetic pigment}

Chlorophyll a: Data represented in figure $4 \mathrm{~A}$ indicated significant genotypic differences in $\mathrm{Chl}$ content in response to $\mathrm{N}$ availability. B73 and Mo17 leaves contained the highest level of $\mathrm{Chl}$ a grown under both $\mathrm{N}$ levels. However, B73 recorded significantly higher Chl a content than Mo17 only when grown under high N. Sids7 and Sids63 leaves had relatively similar level of $\mathrm{Chl}$ a under both $\mathrm{N}$ rates. Compared to their parental inbreds, B73 $\times$ Mo17 leaves had Chl a content at a level similar to or lower than its lower parent (Mo17) grown under both high and low $\mathrm{N}$, respectively. In contrast, Sids7 $\times$ Sids63 leaves had significantly higher $\mathrm{Chl}$ a than its higher parent (B73) under both $\mathrm{N}$ rates. The two hybrids had similar level of Chl a grown under both $\mathrm{N}$ rates. Compared to high $\mathrm{N}$, low $\mathrm{N}$ level decreased $\mathrm{Chl}$ content in all tested genotypes. The low $\mathrm{N}$-induced reductions in $\mathrm{Chl}$ a and recorded $-10.82 \%,-6.35 \%,-30.17 \%$ and $-13.26 \%$ for B73, Mo17, Sids7, and Sids63, respectively. In hybrids, low $\mathrm{N}$ level induced $-23.1 \%$ and $-18.44 \%$ reductions in $\mathrm{Chl}$ a for $\mathrm{B} 73 \times \mathrm{Mo} 17$ and Sids $7 \times$ Sids63, respectively.

Chlorophyll b: The tested inbreds showed relatively similar responses to those of $\mathrm{Chl}$ a under both $\mathrm{N}$ rates (figure 4b). Compared to inbreds, both hybrids had significantly higher level of $\mathrm{Chl} \mathrm{b}$ than their better parents under both $\mathrm{N}$ rates. In addition, the level of $\mathrm{Chl}$ b in B73 $\times$ Mo17 leaves surpassed that in Sids $7 \times$ Sids63 under sufficient and deficient $\mathrm{N}$ supply. Relative to sufficient $\mathrm{N}$, limited $\mathrm{N}$ decreased $\mathrm{Chl} \mathrm{b}$ in all genotypes. Such reductions were $-22.1 \%, 0.0 \%$, $21.54 \%$, and $0.0 \%$ in B73, Mo17, Sids7, and Sids63, respectively. In hybrids, the low $\mathrm{N}$-induced reductions in B73 $\times$ Mo17 and Sids7 $\times$ Sids63 were $-22.18 \%$ and $15.78 \%$, respectively.

\section{Carotenoids}

Figure 4C revealed that the American lines (B73 and Mo17) had significantly higher level of carotenoid than the Egyptian lines (Sids7 and Sids63) at both $\mathrm{N}$ rates without significant difference between members of each pair. Both hybrids contained carotenoids at relatively similar levels to those of their parents under both $\mathrm{N}$ rates. $\mathrm{B} 73 \times$ Mo17 accumulated a significantly higher level of carotenoids than Sids7 $\times$ Sids63 under both $\mathrm{N}$ rates. $\mathrm{N}$-limitation did not induce significant $(p \leq 0.05)$ changes in the level of carotenoids in leaves of the tested genotypes.

\section{Carbohydrates}

\section{Sucrose}

Under high N, B73 and Mo17 contained the highest and the lowest sucrose levels, respectively among inbreds (figure 5a). Sids7 and Sids63 leaves contained intermediate levels of sucrose without significant difference in-between. Under low N, Mo17 leaves maintained the lowest sucrose level whereas the rest of inbreds had relatively similar levels of sucrose in their leaves. B73 × Mo17 leaves contained sucrose level similar to its better parent (B73) whereas Sids7 $\times$ Sids63 has sucrose at a relatively similar level to that of its parent (Sids7) under sufficient N. Under N-limitation, B73 $\times$ Mo17 leaves had a higher sucrose content than its parents whereas Sids7 $\times$ Sids63 leaves had relatively similar sucrose to its better parent (Sids7). Both hybrids contained relatively similar sucrose levels in their leaves under both $\mathrm{N}$ rates. N-limitation significantly $(p \leq 0.05)$ reduced sucrose content in leaves of all genotypes. The $\mathrm{N}$-induced reductions in sucrose concentration were $-33.45 \%,-16.25 \%$, $23.25 \%$ and $-28.76 \%$ in B73, Mo17, Sids7, and Sids63, respectively. In hybrids, the low $\mathrm{N}$-induced reductions were $-22.03 \%$ and $-25.88 \%$ in B73 $\times$ Mo17 and Sids 7 $\times$ Sids63, respectively.

\section{Total soluble sugars (TSS)}

Under high N, B73 leaves had the highest level of TSS, while Mo17 had the lowest TSS level (figure 5B). Leaves of genotype Side 7 and Sids63 showed showed 

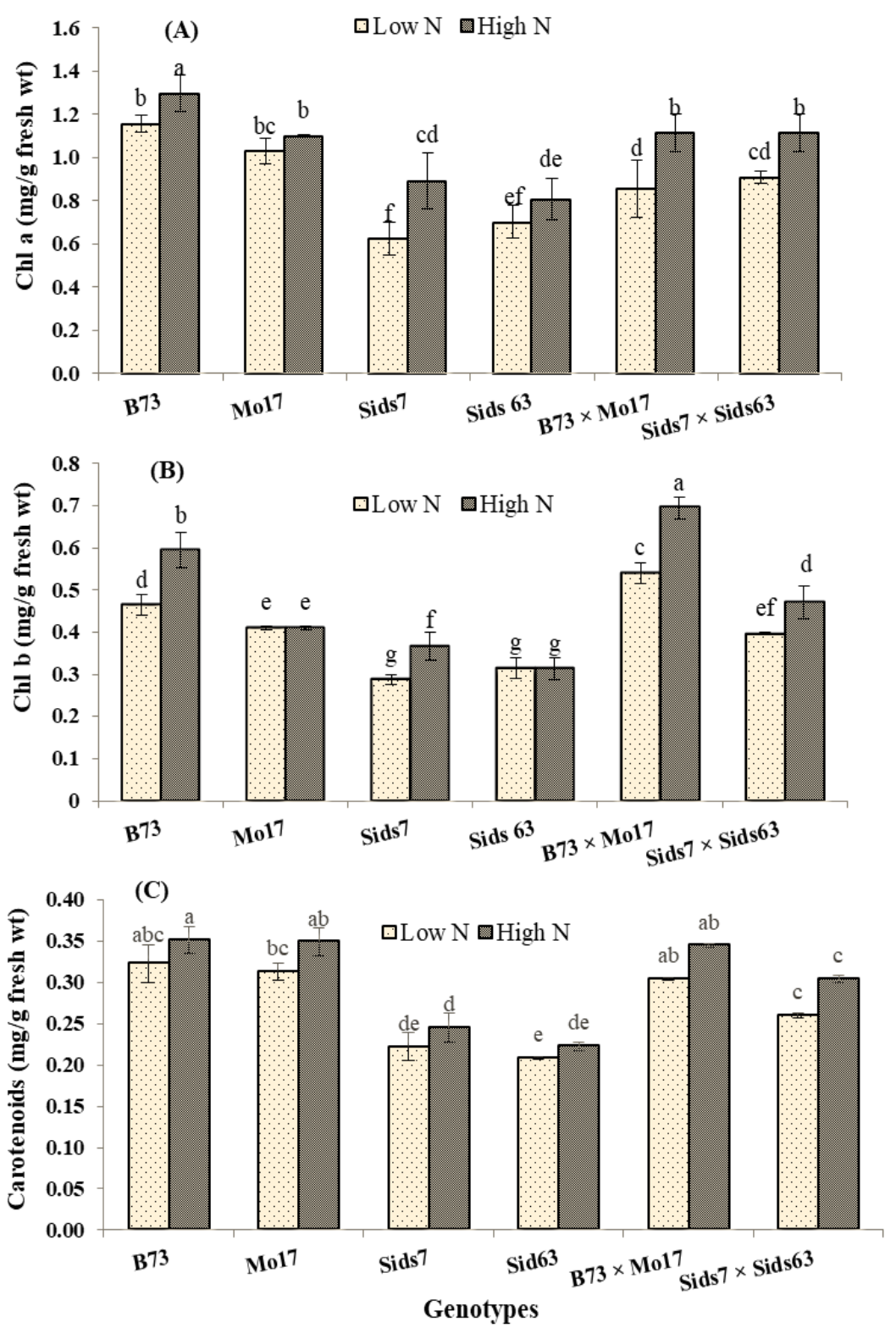

Figure 4. Photosynthetic pigment of maize, inbreds and hybrids, harvested at 45 days of planting and grown under low and high $\mathrm{N}$ input levels. (A), Chlorophyll a content (Chl a); (B), Chlorophyll b content (Chl b); (C), Carotenoid content. Bars with different letters are significantly different $(p \leq 0.05)$. Values are means \pm standard error.

an intermediate levels of TSS without significant difference in-between. Under low N, Sids7 leaves had the highest level of TSS whereas the rest of inbreds had similar TSS content. Compared to inbreds, B73 $\times$ Mo17 leaves had significantly higher TSS than its better parent (B73) and both parents under high and low $\mathrm{N}$ respectively. Sids $7 \times$ Sids63 leaves contained similar TSS to its parents under high $\mathrm{N}$ and equal to its better parent (Sids7) under low N. B73 $\times$ Mo17 had significantly higher TSS than Sids7 $\times$ Sids63 under high $\mathrm{N}$ supply, however both hybrids had similar TSS level under low N. Decreasing N supply caused significant reductions in TSS content in all genotypes. Such reductions were $-32.75 \% \quad(\mathrm{~B} 73),-16.35 \%$ (Mo17\&Sids7) and $-22.25 \%$ (Sids63). The low Ninduced reductions, in B73 $\times$ Mo17 and Sids $7 \times$ Sids63 were $-24.78 \%$ and $-19.59 \%$.

\section{Starch content}

Figure 5C illustrated that B73 and Sids7 recorded about two folds higher starch content, in their leaves, than those of Mo17 and Sids63. However, no significant differences, between members of each pair under both $\mathrm{N}$ rates, were reported. Compared to inbreds, B73 $\times$ Mo17 contained similar level of starch content to its lower parent (Mo17) under studied N rates whereas Sids7 $\times$ Sids63 tended to have an intermediate level of starch to those of its parents. Both hybrids had similar level of starch content under studied $\mathrm{N}$ rates. Interestingly, $\mathrm{N}$-limitation significantly $(p \leq 0.05)$ increased starch content in leaves of all genotypes. The low $\mathrm{N}$-induced increases in inbreds were $90.9 \%, 150 \%, 78.3 \%$, and $280 \%$ in B73, Mo17, Sids7, and Sids63, respectively. In hybrids, such low $\mathrm{N}$-induced starch $\mathrm{N}$-induced starch accumulations 
were $150 \%$ in B73 $\times$ Mo17 and $52.8 \%$ for genotype Sids $7 \times$ Sids63.

\section{Nitrogenous constituents \\ Ammonia-N}

Under sufficient N, B73 leaves had the highest ammonia-N level among inbreds (figure 6A). The other inbreds had relatively similar levels of ammonia- $\mathrm{N}$ in their leaves. Under N-deficient, B73 and Mo17 leaves had the highest and the lowest ammonia-N, respectively. Sids7 and Sids63 had intermediate ammonia-N with Sids7 having higher level than Sids63. Compared to inbreds, B73 $\times$ Mo17 leaves had intermediate level of ammonia-N to that of its parents under both $\mathrm{N}$ conditions. Sids $7 \times$ Sids63 leaves had lower ammonia- $\mathrm{N}$ than its parents under sufficient $\mathrm{N}$ to inbreds, B73 $\times$ Mo17 leaves had similar levels of
amino-N to its parents whereas Sids7 $\times$ Sids63 leaves had significantly lower amino-N than its parents under both $\mathrm{N}$ rates. $\mathrm{B} 73 \times$ Mo17 showed significantly higher concentration of amino-N than Sids $7 \times$ Sids63 under high $\mathrm{N}$ whereas no significant difference was observed between both hybrids under $\mathrm{N}$ limitation. $\mathrm{N}$ deprivation reduced amino-N in all genotypes except Sids7. Such reductions were $-19.12 \%,-40.32 \%,-1.67 \%$, and $30.0 \%$ in B73, Mo17, Sids7, and Sids63, respectively in inbreds whereas the reductions were $-32.06 \%$ in B73 $\times$ Mo17 and $21.85 \%$ in Sids $7 \times$ Sids63. B73 $\times$ Mo17 showed significantly higher concentration of amino-N than Sids7 $\times$ Sids63 under high $\mathrm{N}$ whereas no significant difference was observed between both hybrids under $\mathrm{N}$ limitation. $\mathrm{N}$ deprivation reduced amino-N in all genotypes except Sids7. Such reductions were $-19.12 \%,-40.32 \%,-1.67 \%$, and $30.0 \%$
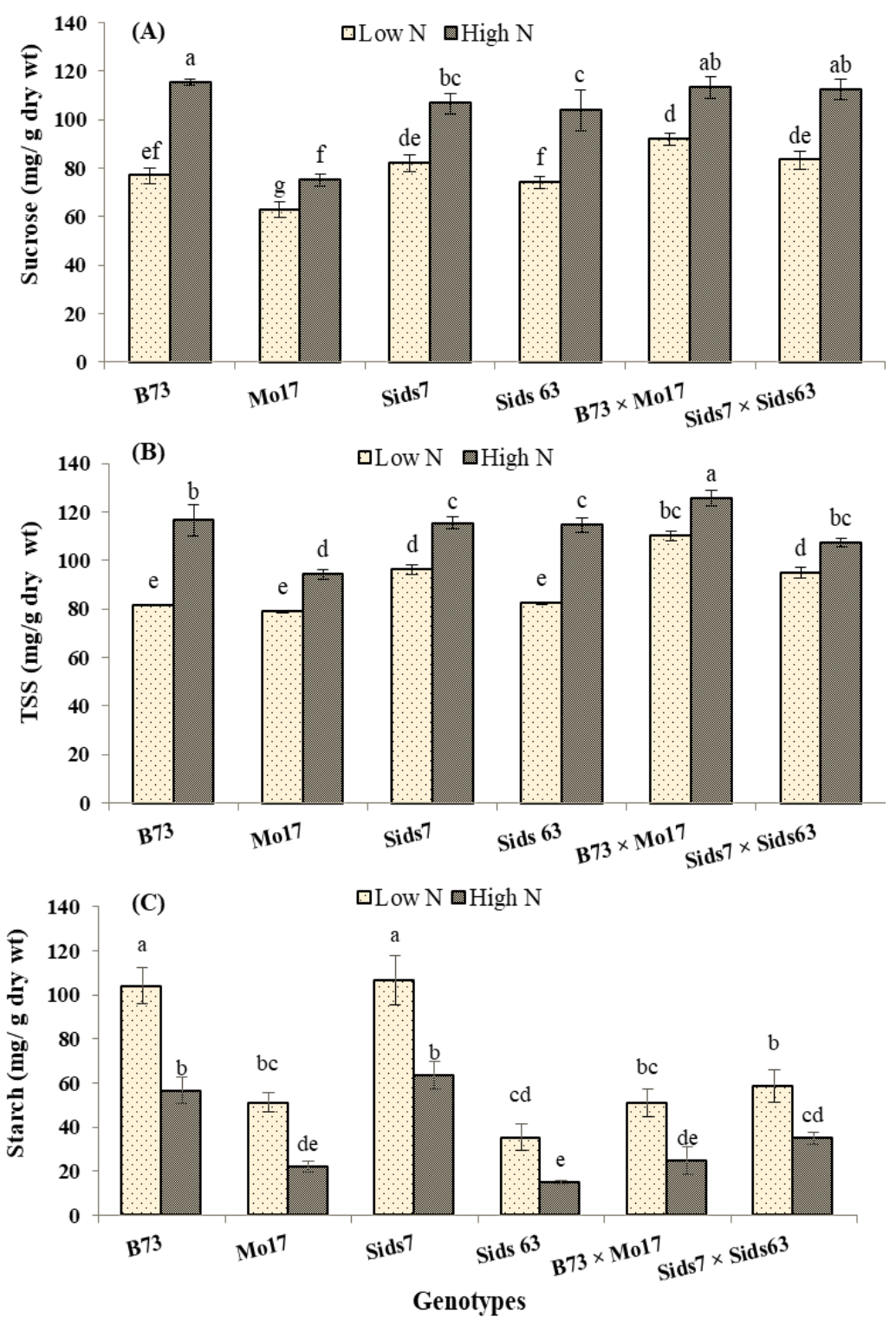

Figure (5): Carbohydrate content of maize, inbreds and hybrids, harvested at 45 days of planting and grown under low and high N input levels. (A), Sucrose content; (B), Total soluble sugars (TSS); (C), Starch content. Bars with different letters are significantly different $(p \leq 0.05)$. Data are in means \pm SE. 
for B73, Mo17, Sids7, and Sids63, respectively in inbreds whereas the reductions were $-32.06 \%$ in B $73 \times$ Mo17 and $21.85 \%$ in Sids $7 \times$ Sids63.

\section{Total Nitrogen content}

B73 and Sids7 leaves had relatively similar level of total $\mathrm{N}$ that was significantly higher than Sids63. Mo17 had the lowest total $\mathrm{N}$ in its leaves among inbreds under sufficient $\mathrm{N}$ (figure 6C). Under $\mathrm{N}$ limitation, Sids7 followed by B73 had significantly higher total $\mathrm{N}$ content in their leaves than Sids63 and Mo17 without significant different between the latter inbreds. In comparison to inbreds, B73 $\times$ Mo17 had total $\mathrm{N}$ content either similar to or lower than that of its better parent (B73) under studied high and low N level, respectively. However, Sids7 $\times$ Sids63 surpassed its better parent (Sids7) in total $\mathrm{N}$ contentunder both $\mathrm{N}$ rates. $\mathrm{N}$ deficiency significantly reduced total-N in all genotypes. Such reductions were $-35.12 \%,-6.34 \%$, $10.48 \%$, and $-37.99 \%$ in B73, Mo17, Sids7 and Sids63, respectively. In hybrids, the percentage of such reductions was $-27.28 \%$ in $\mathrm{B} 73 \times \mathrm{Mo} 17$ and $-33.27 \%$ in Sids $7 \times$ Sids63.

\section{Nitrogen use efficiency (NUE)}

NUE significantly differed $(p \leq 0.05)$ among tested genotypes in response to contrasting $\mathrm{N}$ input levels (figure 7). Under high N, B73, and Sids7 tended to have higher NUE than Mo17 and Sids63 with a significant difference between the later inbreds. Under low $\mathrm{N}$, the differences were more distinct among all inbreds. Meanwhile, genotype B73 followed by Sids7 had significantly higher NUE than those of Mo17 and Sids63.

In hybrids, Sids $7 \times$ Sids63 had similar NUE to its better parent (B73) and its mid-parent under high and low $\mathrm{N}$ respectively. Sids7 $\times$ Sids63 had more than two folds higher NUE than its better parent (Sids7) under both $\mathrm{N}$ treatment. Also, Sids $7 \times$ Sids63 had two folds higher NUE than B73 $\times$ MO17 under both $\mathrm{N}$ inputs. In general, NUE increased with $\mathrm{N}$ deprivation in all genotypes.
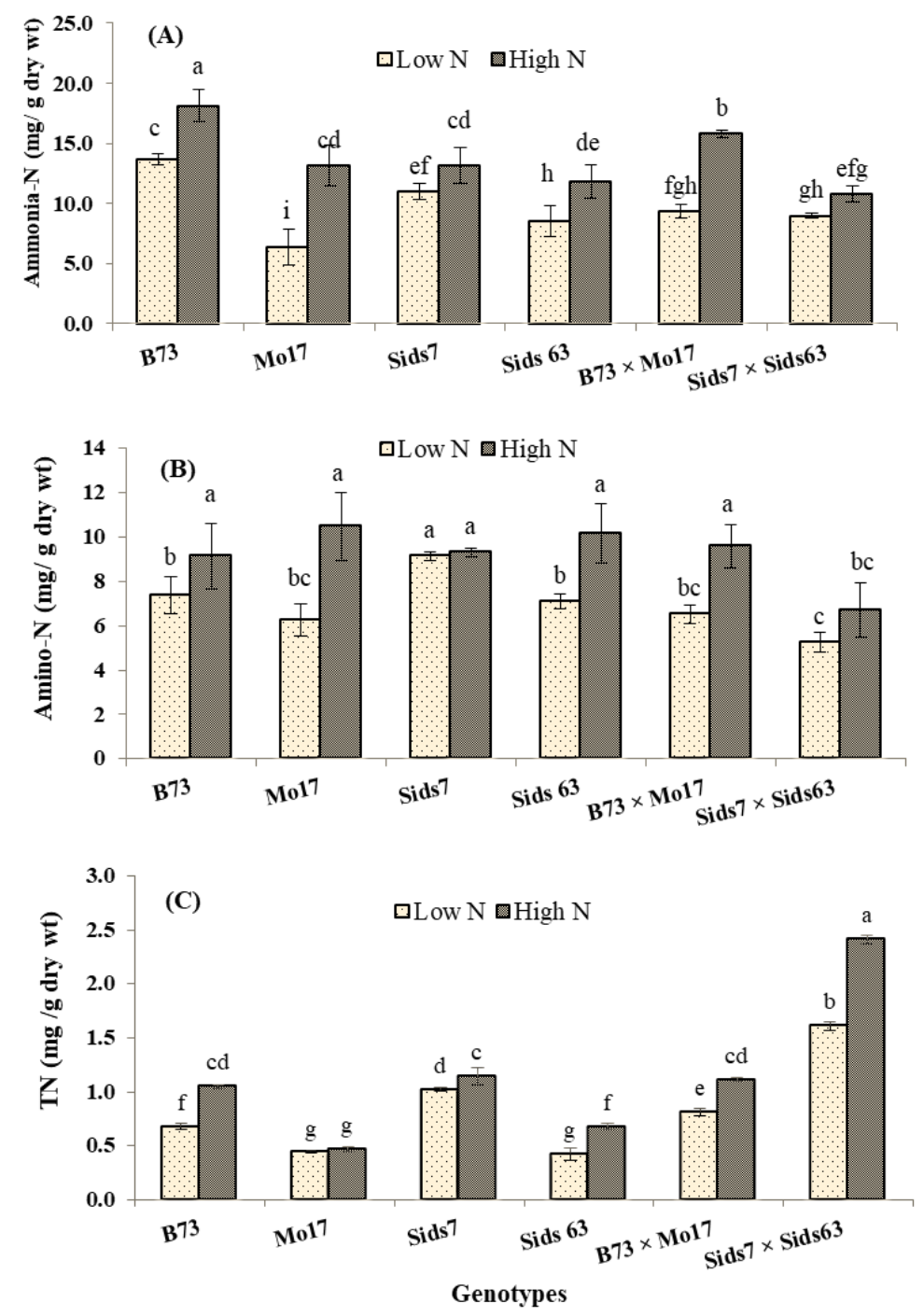

Figure (6): Measured nitrogen content in leaves of maize, inbreds and hybrids, harvested at 45 days of planting and grown under low and high $\mathrm{N}$ input levels. (A), Ammonia-N; (B), Amino-N; (C), Total nitrogen $(\mathrm{TN})$. Bars with different letters are significantly different $(p \leq 0.05)$. Values are means \pm standard error. 


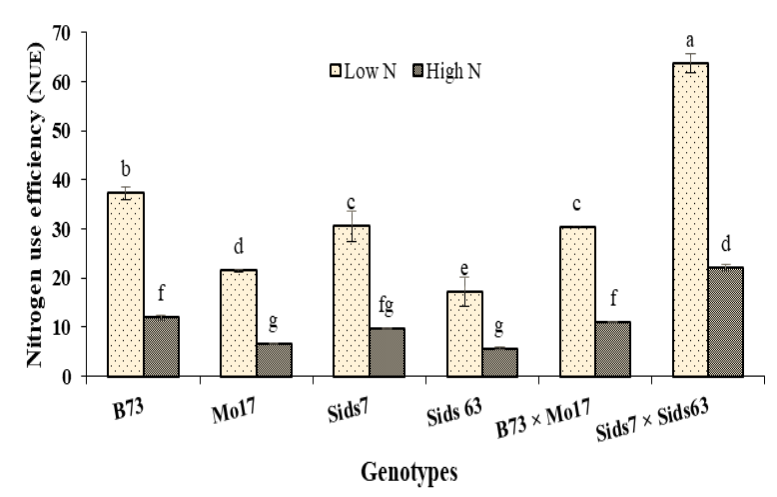

Figure (7): NUE of maize inbreds and hybrids at 45 days of planting and grown under low and high $\mathrm{N}$ input levels. Bars with different letters are significantly different $(p \leq 0.05)$. Values are means \pm standard error.

\section{DISCUSSION}

To gain insights into the "cross-talk" between genetic constitution and physiological processes underlying maize growth in response to sufficient and deficient soil $\mathrm{N}$, the growth and physiological responses in selected maize, inbreds and hybrids, at the critical rapid growth phase (45 days after planting) were simultaneously tested and compared.

\section{Morpho-physiological responses of tested genotypes to $\mathbf{N}$ input levels}

Our growth analysis revealed that the $\mathrm{N}$ fertilization and genotypic had significant effects $(p \leq$ 0.05 ) on the tested morph-physiological traits (figures. 1-3). Biomass accumulation and CGR are considered the best indicators on growth efficiency under various environmental conditions (Catchpole and Wheele, 1992; Chen et al., 2018). B73 and Sids7 were more efficient in biomass accumulation than Mo17 and Sid63 when grown under sufficient and limited $\mathrm{N}$ supply (figure 2A and B). Such superiority was associated with low SLA (figure 3A) which is a good indicator for the photosynthetic efficiency of leaf area unit in biomass production. Therefore, the lower SLA in B73 and Sids7 suggests that these two inbreds would have more efficient photosynthetic capacity and consequently higher CGR than Mo17 and Sids63 under the same $\mathrm{N}$ input levels.

CGR data through 20-day long period (25 - 45 days after planting) supported such a hypothesis and indicated that B73 and Sids7 plants had faster growth rates under high and low $\mathrm{N}$ treatments (figure $3 \mathrm{~b}$ ). Altogether, the data of growth analysis suggest that B73 and Sids7 are more efficient in managing growth under sufficient and deficient soil $\mathrm{N}$ than other inbreds. Such pronounced efficiencies are most likely supported by physiological and/or genetic machineries that favor efficient resource utilization for better growth under adequate and limited $\mathrm{N}$ supply (see below).

\section{Physiological heterogeneity in $\mathrm{C}, \mathrm{N}$ constituents, and NUE}

To gain insights into the physiological mechanisms that operate in green leaves and might stand behind the improved biomass accumulation in B73 and Sids7, key components in carbon and $\mathrm{N}$ metabolism in the leaves were monitored. This is particularly important during vegetative growth where biomass accumulation depends mainly on the efficiency of $\mathrm{C}$ and $\mathrm{N}$ assimilation and the coordination in-between (Schlüter et al., 2012; Jiang et al., 2018). The physiological analysis revealed important points. First, B73 and Sids7 contained significantly higher concentration of sucrose, as the main non-structural component in sugar pool in their leaves than Mo17 and Sids63 under both $\mathrm{N}$ rates (figure 5a). Second, B73 and Sids7 also accumulated more than two folds higher starch as the main temporary storage carbohydrate fraction in their leaves than the other two inbreds (figure 5c). Third, B73 and Sids7 contained significantly higher leaf $\mathrm{N}$ and NUE than Mo17 and Sids63 under both $\mathrm{N}$ rates. These findings reflect effective coordination between $\mathrm{C}$ and $\mathrm{N}$ metabolism in the superior inbreds to secure resources required for the greater plant biomass and rapid growth in B73 and Sids7. Carbon metabolism provides $\mathrm{C}$ required for building carbon skeleton of amino acids necessary for protein biosynthesis. Then proteins, particularly those involved in light harvesting and Calvin cycle, drive efficient photosynthetic capacity in B73 and Sids7. Consistent with that, a strong relation between leaf $\mathrm{N}$, amount of components per unit leaf area, and net photosynthetic rate has been reported in maize, wheat, rice and sugarcane (Makino et al., 1988; Lawlor et al., 2001, Bassi et al., 2018). Further, the higher biomass accumulation of Sids $7 \times$ Sids63, relative to B73 $\times$ Mo17, was also associated with higher leaf $\mathrm{N}$ and consequently higher photosynthetic rates under sufficient and limited $\mathrm{N}$ rates.

\section{Growth and physiological responses in hybrid vs. inbreds}

The growth analysis also revealed that both $\mathrm{B} 73 \times$ Mo17 and Sids $7 \times$ Sids63 gained advantages over their parental inbreds in most growth and leaf features under both $\mathrm{N}$ rates (figure 1-3). Such vigorous growth of hybrids, is attributed to the heterosis phenomenon where growth traits-favoring loci are accumulated and the suppressive ones are complemented (dominance hypothesis) in hybrids. Also, hybrids have the traitcontrolling loci in a heterozygous state which usually has more positive effects on the trait records than those in the homozygous state in inbreds (over dominance hypothesis) (Reif et al., 2005; Hochholdinger and Baldauf, 2018). Physiologically, the superior growth of hybrids over inbreds has been attributed to alterations in enzyme activity, protein metabolism, energy use, mitochondrial metabolism, metabolic balance, circadian clock functions, carbon fixation, phytohormonal level (particularly GA) and cell cycle progression in inbreds and hybrids (Goff, 2010; $\mathrm{Ng}$ et al., 2014; Ko et al., 2016).

Sids7 $\times$ Sid63 was more efficient in biomass accumulation and grew faster than B73 $\times$ Mo17. Its biomass accumulation was about 1.86 and 1.90 folds greater than that of B73 $\times$ Mo17 (figure 2B) whereas 
its crop growth rate was 2.7 and 4 folds higher than B73 $\times$ Mo17 under sufficient and limited $\mathrm{N}$ rates, respectively (figure $2 \mathrm{~B}$ ). Such growth superiority of Sids $7 \times$ Sid63 was associated with significantly lower SLA (figure3A) and thus higher photosynthetic capacity of leaf unit area for biomass production (Poorter et al., 2012). The physiological analysis revealed that, except the superiority of Sids $7 \times \operatorname{Sid} 63$ in leaf $\mathrm{N}$ (figure $6 \mathrm{c}$ ), the two hybrids had relatively similar levels of $\mathrm{Chl} \mathrm{a,} \mathrm{sucrose,} \mathrm{and} \mathrm{starch} \mathrm{in} \mathrm{their}$ leaves (figure $4 \mathrm{~A}$, figure $5 \mathrm{~A}, \mathrm{~B}$ and $\mathrm{C}$ ). Therefore, the growth superiority of Sids $7 \times$ Sid63 over B73 $\times$ Mo17 can be attributed, in part, to its higher leaf area (figure $1 \mathrm{C}$ ) and greater leaf $\mathrm{N}$ (figure 6C). Its higher leaf area increases the efficiency of light capturing whereas higher leaf $\mathrm{N}$ increases the availability of substrates necessary for synthesis of Rubisco and other proteins related to light harvesting, $\mathrm{CO}_{2}$ assimilation, and chloroplast structure/integrity and the overall photosynthetic rate (Pommel et al., 2006). Consequently, more photo assimilates are produced which then drive greater biomass accumulation and enhanced CGR in Sids $7 \times$ Sid63. This hypothesis is supported by the lower SLA of Sids7 $\times$ Sid63 compared to B73 $\times$ Mo17. The similar records of the above mentioned physiological traits in the two hybrids suggest that the Sids $7 \times$ Sid63 has stronger sink tissues than B73 $\times$ Mo17 otherwise its higher photosynthetic capacity would have triggered starch accumulation. Further, the lower starch accumulation in both hybrids, relative to their better inbred parents, also suggest stronger sink in hybrids than inbreds.

\section{Differential tolerance against $\mathrm{N}$ limitation in both inbreds and hybrids}

$\mathrm{N}$ deprivation induced a general reduction in growth, biomass accumulation, CGR, photosynthetic pigment, $\mathrm{N}$ content, and photosynthetic capacity (indirectly implied by sucrose, TSS, and starch measurements), relative to adequate $\mathrm{N}$ application. These results are consistent with many previous studies using open-pollinated maize cultivars (Do Amaral et al., 2018) and hybrids (Qahar and Ahmed, 2016). The general suppressive effects of limited $\mathrm{N}$ reflect the well-known biological significance of $\mathrm{N}$ for plant growth and development. Such inhibitory effects of N deprivation occur via alterations in critical physiological processes such as reduction in nitrate and amino acid metabolism as well as down-regulation of carbon metabolism-related transcripts (Schlüter et al., 2012). Regardless the above general reduction in growth traits, the tested inbreds differed in their sensitivity to low $\mathrm{N}$-induced reduction. To judge such differential genotypic sensitivity to limited $\mathrm{N}$ supply, we used biomass accumulation records as a reliable indicator of the output of spatial and temporal coordination among all plant processes. Accordingly, the tested inbred had the statistical relationships; Mo17>Sids7>B73>Sids63 with low-N induced reductions in biomass accumulation of $-17.97,-21.94$, 22.25 , and $-24.57 \%$, respectively. In hybrids, Sids7 $\times$ Sids63 was relatively tolerant against $\mathrm{N}$ limitation than
B73 $\times$ Mo17 with biomass reduction of $28.07 \%$ and $30.58 \%$, respectively. Therefore the higher records of B73 and Sids7 under low $\mathrm{N}$ treatment do not necessarily mean that they are more tolerant against $\mathrm{N}$ deficiency but rather indicate that B73 and Sids7 have higher genetic potential for growth under both $\mathrm{N}$ rates than Mo17 and Sids6. In hybrids, the relation seems to be more straightforward where Sids7 $\times$ Sids63 maintained higher biomass accumulation under both $\mathrm{N}$ rate as well as relatively high tolerance against $\mathrm{N}$ limitation than $\mathrm{B} 73 \times \mathrm{Mo} 17$.

Unlike the above general suppressive effects of limited $\mathrm{N}$ supply on metabolite responses, it induced significant accumulation of starch in green leaves in all inbreds and hybrids (figure 5b). Interestingly, B73 and Sids7 maintained their superiority in starch accumulation in their leaves over other inbreds and even hybrids. Similar results have been reported in maize (Schlüter et al., 2012; Peng et al., 2014; Ning et al., 2018), tobacco (Paul and Driscoll, 1997) and Arabidopsis (Bi et al., 2007). A possible explanation of starch responses in the current study could be that, under high $\mathrm{N}$ treatment, maize plants maintain proper source/sink relationships where they grow vigorously and develop strong sinks that can effectively accommodate photo assimilates to support and sustain their vigorous growth (figures. 1-3). On the other hand, $\mathrm{N}$ limitation disrupts the source/sink balance via retardation of the overall plant growth and young ear development and thus reduces sink's strength (Hirel et al., 2005; Schluter et al., 2012). Consequently, a significant part of photo assimilates is temporally stored as starch which leads to direct feedback inhibition of photosynthesis in leaves (Iglesias et al., 2002; Schluter et al., 2012). Such starch-driven feedback inhibition of photosynthesis partially explains the low $\mathrm{N}$-induced reduction in photosynthetic carbon assimilation-related components such as photosynthetic pigment (figure 4A and B), sucrose, and TSS (figure $5 \mathrm{~A}$ and $\mathrm{B}$ ). The significantly lower starch concentration in hybrids, relative to B73 and Mo17, indicate that hybrids have stronger sink than inbreds and thus accommodate more photo assimilates. In fact, it has been reported that hybrids maintain proper source/sink relationships than inbreds under sufficient and limited N supply (Hisse et al., 2019).

\section{CONCLUSION}

The current study demonstrated significant heterogeneity in growth and physiological response in the tested inbreds and hybrids under sufficient and deficient $\mathrm{N}$ rates. Such heterogeneity indicates that the potential exists for genetic improvement in NUE in elite maize inbreds and hybrids. The inbred lines B73 and Sids7 seem to have higher genetic potential than the rest of inbreds under sufficient and deficient $\mathrm{N}$ rates. Such high genetic potential enables B73 and Sids7 to employ more efficient strategies to effectively utilize $\mathrm{N}$ for better growth under sufficient and limited N supply. Mo17 and Sids63 are the two extremes in 
tolerance against $\mathrm{N}$ limitation whereas Sids7 and B73 showed relatively similar intermediate capability to tolerate $\mathrm{N}$ limitation. This highlights the significance of the tested inbreds in maize breeding programs.

\section{REFERENCES}

BASSI, D., MENOSSI, M., AND L. MATTIELLO. 2018. Nitrogen supply influences photosynthesis establishment along the sugarcane leaf. Scientific reports. 8(1):2327.

BEADLE, C.L. 1987. Plant growth analysis. In J. Coombs, D.O. Hall, S.P. Long, and J.M.O. Sucrlock (Eds.), Techniques in bio productivity and photosynthesis 2: 21-23. Pregamon Press, Oxford.

BI, M., R.WANG, T.ZHU, AND S. ROTHSTEIN. 2007. Global transcription profiling reveals differential responses to chronic nitrogen stress and putative nitrogen regulatory components in Arabidopsis. BMC Genomics 8: 281.

CATCHPOLE, W. R. AND C. WHEELER. 1992. Estimating plant biomass: a review of techniques. Australian Journal of Ecology. 17(2):121-31.

CHEN, D., R. SHI, J.M. PAPE, K. NEUMANN, D. AREND, A. GRANER, M. CHEN, AND C. KLUKAS. 2018. Predicting plant biomass accumulation from image-derived parameters.Giga Science 7: p.giy001.

CHEN, X., F. CHEN, Y. CHEN, Q. GAO, X. YANG, L. YUAN, F. ZHANG AND G. MI. 2013. Modern maize hybrids in Northeast China exhibit increased yield potential and resource use efficiency despite adverse climate change. Global Change Biology 19(3): 923-936.

CHIBNALL, A. C., M. W. REES, AND E. F.WILLIAMS. 1943. The total nitrogen content of egg albumin and other proteins. Biochemical Journal 37(3): 354.

DAS, B., G. N. ATLIN, M. OLSEN, J. BURGUEÑO, A. TAREKEGNE, R.BABU, E.N. NDOU, K. MASHINGAIDZE, L.MOREMOHOLO, D. LIGEYO, AND R. MATEMBA-MUTASA. 2019. Identification of donors for low-nitrogen stress with maize lethal necrosis (MLN) tolerance for maize breeding in sub-Saharan Africa. Euphotic 215(4): 80.

IBRAHEEM, F. AND EL-GHAREEB, E. M. 2019. Assessment of natural variability in leaf morphological and physiological traits in maize inbreds and their related hybrids during early vegetative growth. Egyptian Journal of Basic and Applied Sciences 6(1): 25-45.

GOFF, S.A. 2010. A unifying theory for general multigenic heterosis: energy efficiency protein metabolism, and implications for molecular breeding. New Phytologist 189(4): 923-937.

HAN, M., M. OKAMOTO, P. BEATTY, S. ROTHSTEIN, AND G.GOOD. 2015. The genetics of nitrogen use efficiency in crop plants. Annual Review of Genetics 49: 269-289.

HANDEL, E.V.1968. Direct micro determinations of sucrose. Analytical Biochemistry 22: 280-3.

HIREL, B., A. MARTIN, T. TERCE-LAFORQUE, M.B. GONZALEZ-MORO, AND J.M. ESTAVILLO. 2005. Physiology of maize I: A comprehensive and integrated view of nitrogen metabolism in a C4 plant. Plant Physiology 124(2): 167-177.

HIREL, B., J. LE GOUIS, B. NEY, AND A. GALLAIS. 2007. The challenge of improving nitrogen use efficiency in crop plants: towards a more central role for genetic variability and quantitative genetics within integrated approaches. Journal of experimental botany 58(9): 2369-2387.

HISSE, I.R., K. E. D'ANDREA, AND M.E. OTEGUI. 2019. Source-sink relations and kernel weight in maize inbred lines and hybrids: Responses to contrasting nitrogen supply levels. Field Crops Research 230:151-9.

HUNT, R. 1978. Plant Growth Analysis: Studies in Biology. London, Edward Arnold London.

HOCHHOLDINGER, F., AND J. BALDAUF. 2018. Heterosis in plants. Current Biology, 28(18), R1089-R1092.

IGLESIAS, D.J., I. LLISO, F.R. TADEO, AND M. TALON. 2002. Regulation of photosynthesis through source:sink imbalance in citrus is mediated by carbohydrate content in leaves. Physiologia plantarum 116:563-572.

JIANG, L., G. BALL, C. HODGMAN, A. COULES, H. ZHAO, AND C. LU. 2018. Analysis of gene regulatory networks of maize in response to nitrogen. Genes 9(3): 151.

KO, D.K., D. ROHOZINSKI, Q. SONG, S. H.TAYLOR, T.E. JUENGER, F.G. HARMON, AND Z.J. CHEN. 2016. Temporal shift of circadian-mediated gene expression and carbon fixation contributes to biomass heterosis in maize hybrids. PLOS Genetics 12: e1006197.

LAWLOR, D.W., G. LEMAIRE, AND F. GASTAL. 2001. Nitrogen, plant growth and crop yield. In P.J. Lea and J-F. Morot-Gaudry (Eds.). Plant nitrogen: 343-367. Berlin, Springer-Verlag.

LAWLOR, D.W., M. KONTTURI, AND A.T. YOUNG. 1989. Photosynthesis by flag leaves of wheat in relation to protein, ribulose bisphosphate carboxylase activity and nitrogen supply. Journal of Experimental Botany 40(1): 43-52.

MAKINO, A., T. MAE, AND K. OHIRA. 1988. Differences between wheat and rice in the enzymic properties of ribulose-1,5-bisphosphate carboxylase/oxygenase and the relationship to photosynthetic gas exchange. Planta 174(1): 30-38.

MASCLAUX-DAUBRESSE, C., F. DANIELVEDELE, J. DECHORGNAT, F. CHARDON, L. GAUFICHON, AND A. SUZUKI. 2010. Nitrogen 
uptake, assimilation and remobilization in plants: Challenges for sustainable and productive agriculture. Annals of botany 105(7): 1141-1157.

MASTRODOMENICO, A., C. HENDRIX, AND F. BELOW. 2018. Nitrogen use efficiency and the genetic variation of maize expired plant variety protection germplasm. Agriculture 8(1): 3-17.

METZNER, H., H. RAU, AND H. SENGE. 1965. Untesuchungen zur synchronisierbarteit einzeluer pigmentan angel mutanten van chlorella. Planta 65(2): 186-90.

MOOSE, S. P., J. W. DUDLEY, AND T. R. ROCHEFORD. 2004. Maize selection passes the century mark: a unique resource for 21 st century genomics. Trends in plant science 9(7): 358-364.

MOUSA, E., E. SADEK, AND M. EL-NAHRAWY. 2017. Silage yield and quality of some maize and teosinte genotypes and their hybrid. AmericanEurasian Journal and Agriculture and Environmental Science 17: 373-8.

MUTING, D. AND E. KAISER. 1963. Spectrophotometric method of determination of $\alpha$ amino- $\mathrm{N}$ in 629 biological material by means of the ninhydrin reaction. Hopper seyler's Zeitschrift Für Physiologische Chemie 332: 276-89.

NAGUIB, M. I. 1964. Effect of sevin on carbohydrates and nitrogen metabolism during the germination of cotton seeds. Indian Journal of experimental Biology 2: 149-155.

NAZIR, M., R. PANDEY, T. O. SIDDIQI, M. M. IBRAHIM, M. I. QURESHI, G. ABRAHAM, K.VENGAVASI, AND A. AHMAD. 2016. Nitrogen- deficiency stress induces protein expre-ssion differentially in low-N tolerant and low-N sensitive maize genotypes. Frontiers in plant science 7: 1-16.

NG, D.W.K., M. MILLER, H. Y. HELEN, T. Y. HUANG, E. D. KIM, J. LU, Q. XIE, C. R. MCCLUNG, AND Z.J. CHEN. 2014. A role for $\mathrm{CHH}$ Methylation in the parent-of-origin effect on altered circadian rhythms and biomass heterosis in Arabidopsis intraspecific hybrids. The Plant Cell 26(6): 2430-40.

NING, P., Y. PENG, AND F. FRITSCHI. 2018. Carbohydrate Dynamics in Maize Leaves and Developing Ears in Response to Nitrogen Application. Agronomy 8(12): 302.

NOOR, M.A. 2017. Nitrogen management and regulation for optimum NUE in maize-A mini review. Cogent Food \& Agriculture. 3(1):1348214.

Do AMARAL, C.B., DE OLIVEIRA, G.H., MORO, G.V. 2018. Phenotyping open-pollinated maize varieties for environments with low nitrogen availability. Archives of Agronomy and Soil Science. 64(10):1465-72.

PAUL, M.J. AND S.P. DRISCOLL. 1997. Sugar repression of photosynthesis: the role of carbohydrates in signalling nitrogen deficiency through source: sink imbalance Plant, cell \& environment 20(1):110-116.
PENG, Y., C. LI, AND F. B. FRITSCHI. 2014. Diurnal dynamics of maize leaf photosynthesis and carbohydrate concentrations in response to differential $\mathrm{N}$ availability. Environmental and experimental botany 99: 18-27.

POMMEL, B., A. GALLAIS, M. COQUE, C. QUILlERÉ, B. HIREL, J. L. PRIOUL, B. ANDRIEU, AND M. FLORIOT. 2006. Carbon and nitrogen allocation and grain filling in three maize hybrids differing in leaf senescence. European Journal of Agronomy 24(3): 203-211.

POORTER, H., J. BÜHLER, D. VAN DUSSCHOTEN, J. CLIMENT, AND J. A. POSTMA. 2012. Pot size matters: a meta-analysis of the effects of rooting volume on plant growth. Functional Plant Biology 39(11): 839.

QAHARR, A. AND B. AHMAD. 2016. Effect of nitrogen and sulfur on maize hybrids yield and post-harvest soil nitrogen and sulfur. Sarhad Journal of Agriculture. 32(3):239-51.

REIF, J.C., A. R. HALLAUER, AND A. E. MELCHINGER. 2005. Heterosis and heterotic patterns in maize. Maydica 50(3/4): 215.

SCHLÜTER, U., M. MASCHER, C. COLMSEE, U. SCHOLZ, A. BRÄUTIGAM, H.FAHNENSTICH AND U. SONNEWALD. 2012. Maize source leaf adaptation to nitrogen deficiency affects not only nitrogen and carbon metabolism but also control of phosphate homeostasis. Plant Physiology 160(3): 1384-1406.

SHAROPOVA, N., M. D. MCMULLEN, L.SCHULTZ, S. SCHROEDER, H.SANCHEZVILLEDA, J. GARDINER, D. BERGSTROM, K. HOUCHINS, S. MELIA-HANCOCK, T.MUSKET, AND DURU, N. 2002. Development and mapping of SSR markers for maize. Plant molecular Biology 48(5-6): 463-481.

TAKASHIMA, T., K. HIKOSAKA, AND T. HIROSE. 2004. Photosynthesis or persistence: nitrogen allocation in leaves of evergreen and deciduous Quercus species. Plant, Cell \& Environment 27(8): 1047-1054.

THAYERMANAVAN, V. AND S.SADASIVAM. 1984. Qual plant foods hum nutr., 34, 253- 257. In:S. Sadasivam and A. Manickam (eds). Biochemical Methods 2nd ed: 11-12. New age. inter. limit. publ. New Delhi, India.

TOLLENAAR, M. AND E. A. LEE. 2002. Yield potential, yield stability and stress tolerance in maize. Field Crops Research 75(2-3): 161-169.

WORKU, M., M. BÄNZIGER, D. FRIESEN, AND W. J. HORST. 2007. Nitrogen uptake and utilization in contrasting nitrogen efficient tropical maize hybrids. Crop Science 47(2): 519-528.

XIANG-LING, L. I., G. U. O. LI-GUO, Z. BAOYUAN, T. XIANG-MING, C. CONG-CONG, AND Z. LEI. 2019. Characterization of low-N responses in maize (Zea mays L.) cultivars with 
contrasting nitrogen use efficiency in the North China Plain. Journal of Integrative Agriculture 18: 2-13. (2019).

YEMM, E. W. AND A. J. WILLIS. 1956. The respiration of barley plants: IX. The metabolism of. roots during the assimilation of nitrogen. New Phytologist 55(22): 229-252.
ZHANG, C., J. ZHANG, H. ZHANG, J. ZHAO, Q.WU, Z.ZHAO, AND T. CAI. 2015. Mechanisms for the relationships between water-use efficiency and carbon isotope composition and specific leaf area of maize (Zea mays L.) under water stress. Plant growth regulation 77(2): 233-243.

\title{
النمو والاستجابات الفسيولوجية لسلالات الذرة النقية والهجينة تحت تركيزات عالية ومنخفضة لنيتروجين التربة

\author{
فرج إبر اهيم1، 2*، إيمان الغريب1

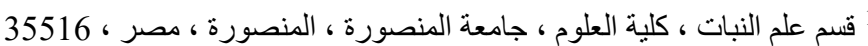 \\ 2 شعبة الاحياءـ الكلية الجامعية بالقنفذة جامعة جامعة أم القرى- المملكة العربية السعودية ـ 1109
}

\begin{abstract}
الملخص العربــي

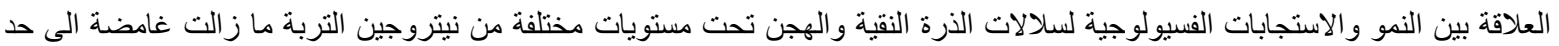

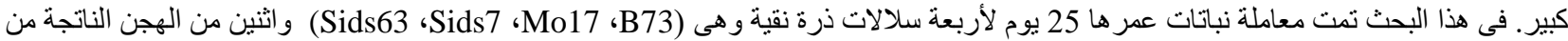

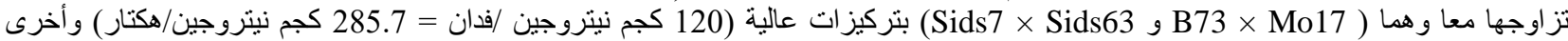

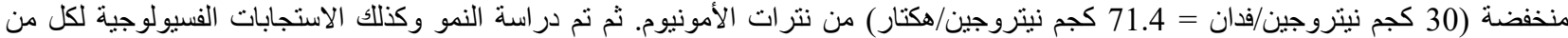

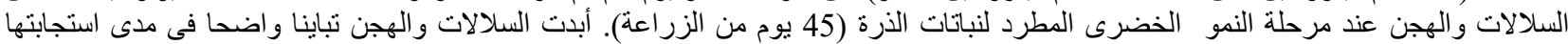
لنقص ووفرة النيتروجين فى التربة .تفوقت كل من سلالات

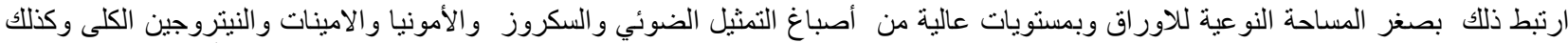

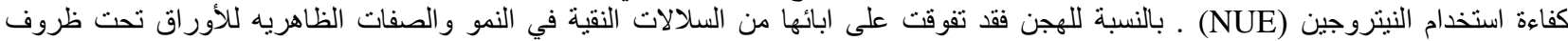

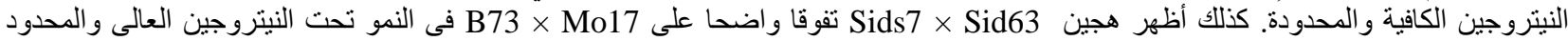

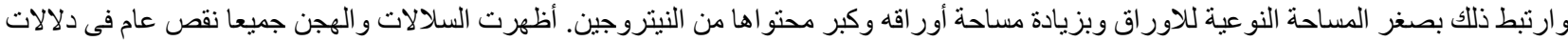

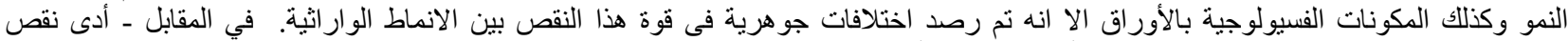

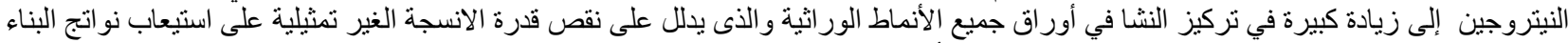

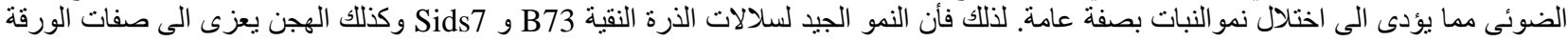

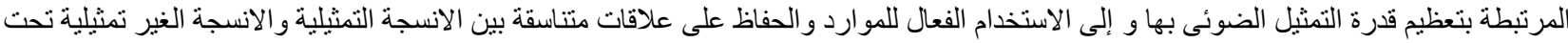
ظروف نقص وكفاية نيتروجين التربة.
\end{abstract}

